\title{
陳旧性橈骨頭脱臼の治療経験
}

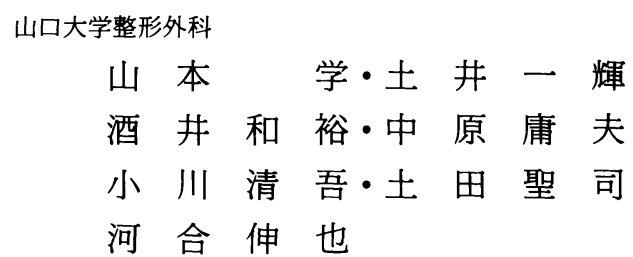

\section{Treatment of Old Radial Head Dislocation}

by

\author{
Manabu Yamamoto, Kazuteru Doi, Kazuhiro Sakai, \\ Tsuneo Nakahara, Seigo Ogawa, Seiji Tsuchida \\ and Shinya Kawai \\ Department of Orthopedic Surgery, \\ Faculty of Medicine,Yamaguchi University, Ube, Japan
}

\begin{abstract}
Thirteen cases of old radial head dislocation were treated in our department. The radial head was reduced by corrective osteotomy of the ulna in 6 casee with old Monteggia fractures and by annular ligament reconstruction in 2 cases of isolated radial head dislocations. Radial head resection was performed in 3 cases with severe limitation of ROM. Two cases with no limitation of ADL were followed conservatively. The time from injury to operation ranged from 2 months to 10 years.

Reduction of radial head was maintained in 2 out of 6 cases treated with corrective ostotomy of the uina. In 2 cases where surgery was performed within 3 months after injury the radial heads were completely reduced. In 4 cases within 1 to 10 years they were dislocated or subluxated.

Corrective onteotomy is useful for radial head reduction if the clinical symptoms, age, time from injury and deformity of radial head are taken into consideration.
\end{abstract}

\section{はじめに}

陳旧性橈骨頭脱臼に対して橈骨頭を整復するかどう か，いまだ議論の多いところである。この度少数では あるが自験例について検討したので報告する。

\section{対象}

症例は 13 例で，その原因疾患は Monteggia 骨折 6 例, 橈骨頭単独脱臼 7 例である. 年齢は 5 歳から 55 歳 で，10 歳以下が 4 例， 11 歳から 15 歳の年長児が 6 例 に認められた，原因の明らかでない 2 例では肘前面に 骨性膨隆を認めたときを発症とすると，受傷後あるい は発症後経過期間は 2 ケ月から 10 年で, 受傷後 1 年末
満は 7 例， 1 年以上経過例を 6 例に認めた。当科初診 時の愁訴としては, 可動域制限を 10 例に, 変形, 疼痛 をそれぞれ 7 例に，しびれを 1 例に認めたが，概して 愁訴の軽い症例が多く ADL 障害を訴えたものは 3 例 のみであった。

これら 13 例に対して, 観血的治療を 11 例に行い, 症状の軽微な 2 例で保存的に経過観察を行った．観血 的治療は陳旧性 Monteggia 骨折 6 例に対して尺骨矯 正骨切りを, 機能障害の著しい 3 例に橈骨頭切除を, また輪状勒带再建術は単独脱臼例 2 例に施行した。

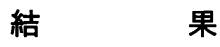

橈骨頭切除の可動域に対する効果は確実であったの 
に対して，尺骨矯正骨切り術施行例では内旋制限をき たす症例が多く認められ，輪状勒帯再建術施行例では 著明な回旋制限をきたした。保存的に経過観察を行っ た 2 例では, 経年的に可動域の減少傾向を認めたが, ADL 障害をきたすほどの減少は認めなかった.

尺骨矯正骨切りを施行した 6 例について, 調査時に 橈骨頭の完全な整復位が維持されていた症例は 2 例の みで，3 例は亜脱臼位，1例は完全脱臼位を呈してい た.この整復位が得られていた 2 例では骨切り部位は 尺骨骨幹部よりであると共に，整復位が得られなかっ た 4 例に比べて, より大きな延長量と矯正角度が獲得 されていた．手術手技が改善される余地はあると考え られたが, 両群の最も異なる点は, 受傷後経過期間と 橈骨頭の形態であった。すなわち，整復位の得られな かった 4 例はいずれも受傷後長期を経過し橈骨頭の変 形・肥大が出現している症例であったのに対して, 整 復位が得られた 2 例は, ともに受傷後 3 ケ月の症例で, 単純 X 線での橈骨頭の変化を認めなかった（表 1 ).

\section{症例}

15 歳男性で, 陳旧性 Monteggia 骨折の症例である. 受傷後 7 年で肘関節部痛を主訴に当科受診した. ADL 障害を認めなかったが，肘の不安定性のためスポーツ 活動への参加が制限されているため, 尺骨矯正骨切り と橈骨頭の観血的整復術を施行した. 術中所見として， 橈骨頭，上腕骨小頭は共に山凸不整で腕橈関節の適合 性は良好とは言えなかったが，尺骨の後方凸への矯正 と延長を加えることにより橈骨頭は容易に整復され た. 術後 1 年の現在, 时関節部の疼痛と外反動摇性は 消失しているが，回内位で車脱臼し，また回内が 15 度 と制限されており，日整会肘関節機能判定基準では術 前 86 点が術後 89 点と軽度の改善が得られたのみであ る(図 1 )。

\section{考察}

橈骨頭脱臼が放置されると, 疼痛や外反时，可動域 制限，さらには遠位橈尺関節障害や橈骨・尺骨神経麻 痺などが発生することが報告されている。とりあえず 保存的治療で対処し，機能障害が著しい場合橈骨頭を 切除すると言う意見もあるが，陳旧例においても，特 に小児に扔いては安定した肘関節を再建すると言う観 点から，可能な限り橈骨頭を整復することが望ましい と考える。このために，尺骨矯正骨切りや輪状鞀帯再
表 1 尺骨矯正骨切り術 6 例

\begin{tabular}{ccc} 
& 整復位 2 例 & 非整復位 4 例 \\
\hline 年 齢 & 平均 11 歳 & 平均 13 歳 \\
受傷後経過期間 & 3 ケ月 & 5.8 年 \\
橈骨頭の変化 & 全例なし & 全例あり \\
手術手技 & & \\
観血的整復 & & 全例で併用 \\
骨切り部 & &
\end{tabular}

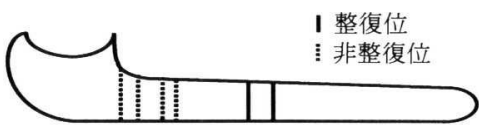

尺骨延長量

(術後一術前) / 術前 $\times 100$ 平均 $6 \%$ 平均 $4 \%$ uhar variant の増加 $\quad 4.0 \mathrm{~mm} \quad 2.7 \mathrm{~mm}$ 矯正角度

$23^{\circ}$

$16^{\circ}$

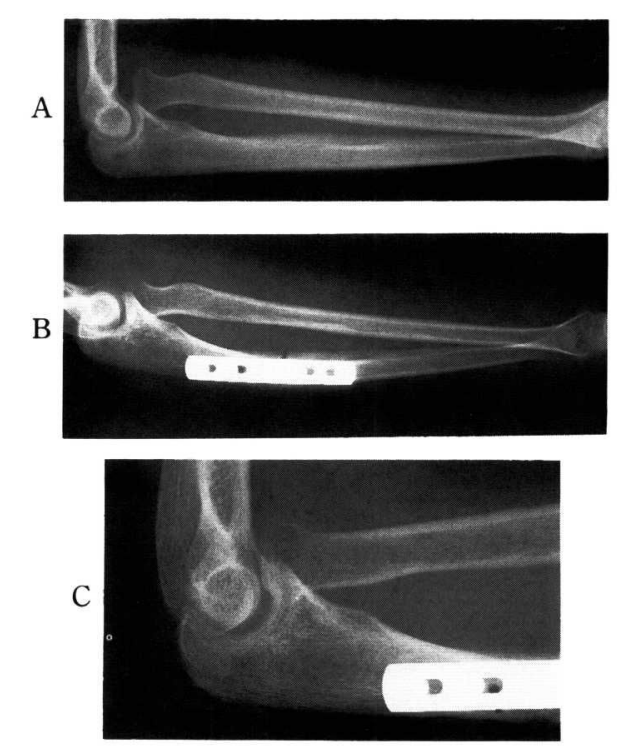

図 1 症例 15 歳男性 Monteggia 骨折受傷後 7 年 A. 術前 B. 術直後 C. 術後 1 年

建などの観血的治療が行われているが，いずれの方法 もいくつかの問題点があり, 保存的治療や橈骨頭切除 も含めて治療法の選択は慎重に行われるべきであると 言える.

陳旧性橈骨頭脱臼の原因として最も多い Monteggia 骨折後の症例は，尺骨の弯曲と短縮に起因するも

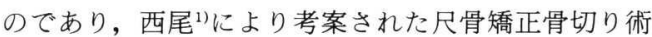
はより病態に即した手術方法であると言え，その治療 
成績も良好であることが報告されている2)。しかしな がら，呈示した症例のように受傷後長期経過した例で は，橈骨頭の肥大変形した例が多く，整復状態が不良 であったり，回旋制限を認める例が少なからず存在す る. 良好な治療成績を得るためには, 臨床症状に加え て年齢や受傷後経過期間)を考慮し，本術式を選択す る必要があると考える。

$$
\text { ま と め }
$$

陳旧性橈骨頭脱臼 13 例の治療成績について検討し た。安定した时関節の再建には尺骨矯正骨切りが有用
であるが，年齢や受傷後経過期間を考慮し本術式を選 択する必要があると考える。

\section{参 考 文 献}

1）西尾篤人：尺骨骨切り術による陳旧性 Monoeggia 骨折の治療法について, 災害医学, 8:60-72, 1965.

2) 河井秀夫：外鹪性橈骨頭脱臼陳旧例の检討. 日関外 誌, 9:391-396, 1990 .

3）三浪明男：Monteggia 骨折の診断と治療. Orthopedics, $36: 87-97,1991$. 